\title{
Helminthosporium Leaf Spot of Corn Caused by Bipolaris zeicola in Japan
}

\author{
Takao Tsukiboshi*, Toru Sato** and Takashi Kimigafukuro*
}

Key words : Bipolaris zeicola, Helminthosporium leaf spot, corn.

In 1981, the occurrence of a leaf spot on corn caused by Bipolaris sp. was reported by Nishihara ${ }^{11}$. The disease was first observed in June, before the occurrence of southern corn leaf blight caused by Bipolaris maydis. Symptoms on mature corn plants in the fields were characterized by narrow, linear lesions and the lesion size was about 5-20 $\times 0.5-2 \mathrm{~mm}$. Lesions were grayish-tan and surrounded by a light- to darkly-pigmented border. The disease which occurs mainly in the northern part of Japan is becoming prevalent in the Hokkaido, Tohoku and Kanto Districts. Since the causal agent was considered to be Bipolaris zeicola, the causal fungus of Helminthosporium leaf spot, on the basis of the morphology of its anamorph, several isolates of $B$. zeicola were introduced from the United States of America in order to identify the Japanese isolates by comparing their morphological characteristics and by carrying out crossing experiments.

The 19 monoconidial isolates were obtained from leaf lesions on plants collected in Hokkaido, Aomori. Tochigi and Nagano Prefectures. Four of these isolates were incubated on V-8 juice (Campbell Soup Co.) agar at $22 \mathrm{C}$ under constant fluorescent lighting for seven days. Simultaneously, three American isolates, NI848, NI926 and NI1099, were incubated and the morphology of their anamorph was compared with that of the Japanese isolates. Conidiophores were straight or flexuous, $60-200 \mu \mathrm{m}$ long in the Japanese isolates and 70-190 $\mu \mathrm{m}$ long in the American isolates. In both isolates, each proliferation of conidia on the upper portion of the conidiophores was very short, giving the conidiophores a distinctive geniculate appearance. Proliferation usually occurred on all sides of the conidiophore, giving the conidia a whorled appearance. Conidia were straight or moderately curved, dark or olivaceous brown, the cells of the terminal portion sometimes appearing paler than those of the middle one. The results of measurement of conidia of the Japanese and American isolates are shown in Table 1. Although the conidia of the Japanese isolates were slightly longer than those of the American isolates, the width of conidia and the number of septa of the former were very similar to the latter.

Crossing of the Japanese isolates and the American isolates was also attempted. Cochliobolus carbonum Nelson, the teleomorph of B. zeicola, is a heterothallic Ascomycete

\footnotetext{
* National Grassland Research Institute, 768 Nishinasuno, Tochigi 329-27, Japan 草地試験場

** Hokkaido National Agricultural Experiment Station, 1 Hitsujigaoka, Sapporo 061-01, Japan 北海 道農業詮駼場

1) Nishihara, N. (1981). Ann. Phytopath. Soc. Japan $47: 367$.
} 
Table 1. Comparative measurements of conidia of the Japanese and American isolates

\begin{tabular}{c|c|c|c}
\hline \hline Isolate number (Origin) & Conidial length $(\mu \mathrm{m})$ & Conidial width $(\mu \mathrm{m})$ & Number of septa \\
\hline BZ 1001 (Aomori) & $\left.78.9^{\mathrm{a}}\right)$ & 13.5 & 8.2 \\
1105 (Hokkaido) & 83.0 & 13.7 & 8.4 \\
1207 (Tochigi) & 82.1 & 13.7 & 8.5 \\
1303 (Nagano) & 80.4 & 13.9 & 8.7 \\
NI 848 (USA) & 76.5 & 13.4 & 8.0 \\
926 (USA) & 71.0 & 13.1 & 8.1 \\
1099 (USA) & 75.9 & 13.3 & 8.4 \\
\hline
\end{tabular}

a) Each value is the mean of 300 conidia.

and cross-fertility is controlled by a single major gene locus for mating type, designated as $A-a^{2)}$. Each Japanese isolate was crossed with two American isola'es, NI926 and NI1099, of mating type A and a, respectively. Crossing procedures described by Nelson ${ }^{3)}$ were adopted with slight modifications, as described below. Crossing was performed by placing a small piece of mycelium on the opposite sides of a section of sterile wheat straw in the center of a Petri plate containing Sach's nutrient agar ( $\mathrm{pH} \mathrm{5}$ ). All the crossing materials were incubated continuously at $20^{\circ} \mathrm{C}$ under constant fluorescent lighting. Cross-fertility of paired cultures was determined after 30 days.

Among the 19 isolates tested, 11 were crossed with the American isolates; 10 were mating type $A$ and 1 was a. The predominance of mating type $A$ suggests the recent occurrence of this disease in Japan ${ }^{4}$. Mature pseudothecia were black and ellipsoidal to globose. They measured $370-800 \mu \mathrm{m}$ in height and $360-620 \mu \mathrm{m}$ in diameter. A welldefined ostiolate beak, $80-250 \mu \mathrm{m}$ long, was usually produced. Asci were cylindrical to clavate, and straight or slightly curved, with a short stipe. They measured 120-240X 13.8-31.3 $\mu \mathrm{m}$ (mean $172 \times 20.8 \mu \mathrm{m}$ ). Asci contained 1-8 ascospores coiled in a close helix. Ascospores were filiform or flagelliform, hyaline, with 4-13 septa, and measured $150-300 \times 3.8-8.8 \mu \mathrm{m}$ (mean $223 \times 6.3 \mu \mathrm{m}$ ). These characteristics of the teleomorph were close to those of $C$. carbonum judging from the original publication on this species ${ }^{3}$.

Based on the observations recorded above, the causal fungus of corn leaf spot in Japan was identified as follows;

Anamorph: Bipolaris zeicola (Stout) Shoemaker

\section{$=$ Helminthosporium carbonum Ullstrup}

Teleomorph: Cochliobolus carbonum Nelson

In Helminthosporium leaf spot, three races can be differentiated according to the reaction of susceptible corn lines ${ }^{5,6}$. Isolates of race 1 produce well-defined, zonate lesions on specific corn lines and race 2 isolates produce chlorotic flecks. Isolates of race 3 which was identified in 1973 produce long, linear lesions. Most of the Japanese isolates are considered to belong to race 3 on the basis of their lesion type, but further

2) Nelson, R. R. (1960). Phytopathology $50: 158-160$. 3) Nelson, R. R. (1959). Ibid. $49: 807-810$. 4) Leonard, K. J. (1971). Plant Dis. Reptr. $55: 759-760$. 5) Ullstrup, A. J. (1941). Phytopathology $31: 508-521$. 6) Nelson, R. R., Blanco, M., Dalmacio, S. and Shain Moore, B. (1973). Plant Dis. Reptr. $57: 822-823$. 
studies are necessary to determine which races they belong to.

We wish to express our thanks to Dr. K. J. Leonard, North Carolina State University, for supplying the isolates of $B$. zeicola. We thank Dr. M. Tsuda, Kyoto University, for his helpful suggestions for the preparation of the manuscript.

\section{和 文 摘 要}

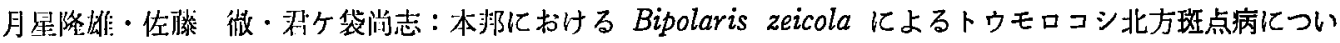
$\tau$

1981 年西原が Bipolaris sp. として報告したトウモロコシ北方斑点病菌の同定を行った。本菌の無性世代の 形態から B. zeicola と考えられたため, 同菌株をアメリカ合䋸国より輸入して, 日本分踓菌株との比较試験を 行った。北海道, 暃森, 杤水および長野の各県て採集した19菌怢を供試し，アメリカ榆入菌株との形態比較を 行ったところ，分生胞子柄および分生胞子の形，大きさのいずれも一致した。次に，アメリカ輸入菌株との交 配武験を行ったところ，19菌粎中11菌株が交配し，子のう胞子を形成した。偽子のう殸，子のうおよび子のう 胞子の北態もCochliobolus carbonum (B. zeicola の有性世代) の原記武に一致した。よって, 本菌を Bipolaris zeicola (Stout) Shoemaker (有性扑代 Cochliobolus carbonum Nelson) と同定した。

(Received January 9, 1986)

\section{Explanation of plate}

\section{Plate I}

Fig. 1,2. Symptoms of Helminthosporium leaf spot on corn in the field at Tokachi, Hokkaido.

Fig. 3. Conidia of the American isolate, NI926.

Fig. 4. Conidia of the Japanese isolate, BZ1207.

Fig. 5. Conidiophores and conidia of the isolates, NI848 (left) and BZ1105 (right), with whorled appearances.

Fig. 6. Pseudothecia partially immersed in the wheat straw.

Fig. 7. Pseudothecium.

Fig. 8. Asci with ascospores coiled in a close helix.

Bars in Fig. 3, 4, 8 and Fig. 7 represent $50 \mu \mathrm{m}$ and $200 \mu \mathrm{m}$, respectively. 


\section{Plate I}
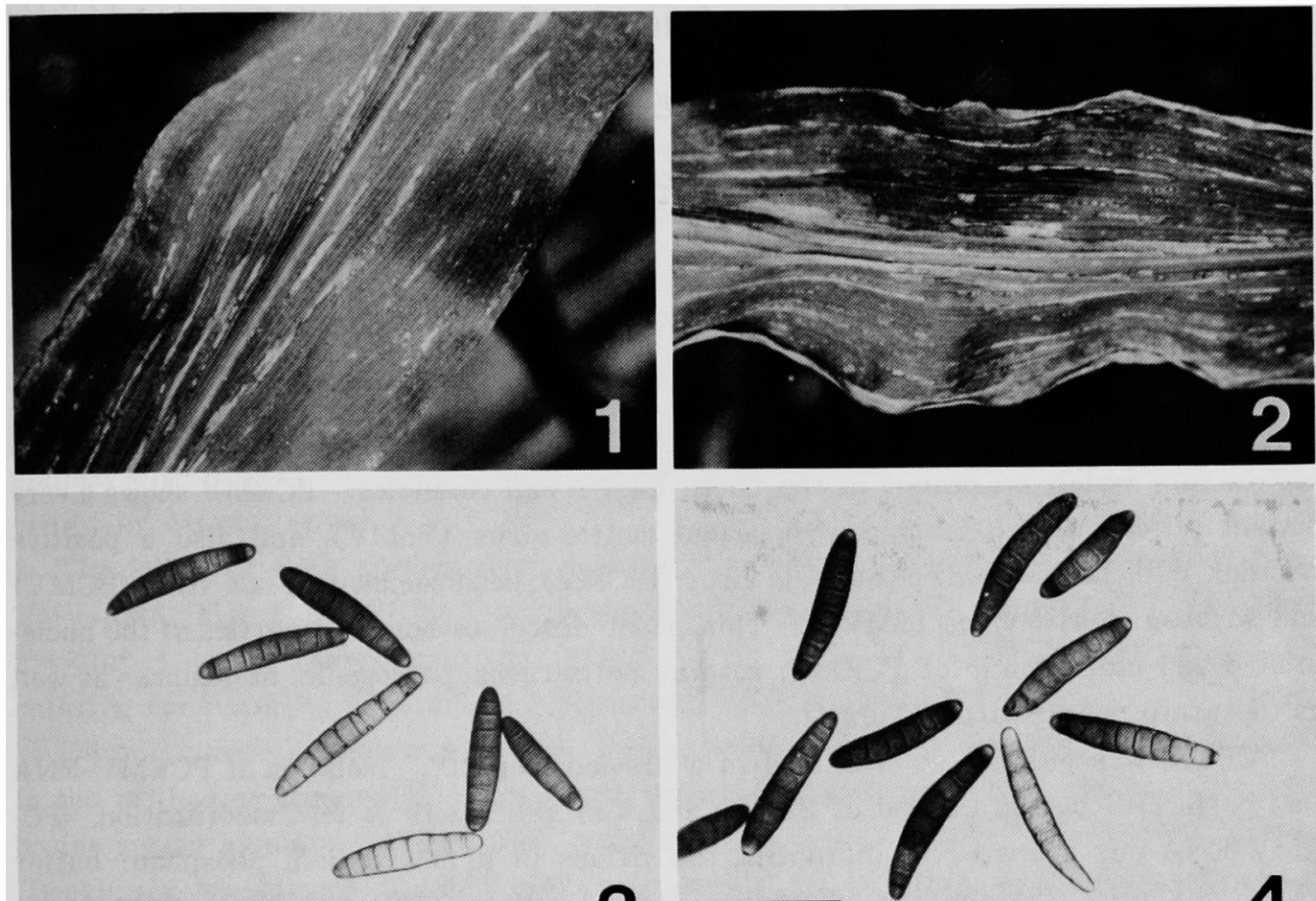

3
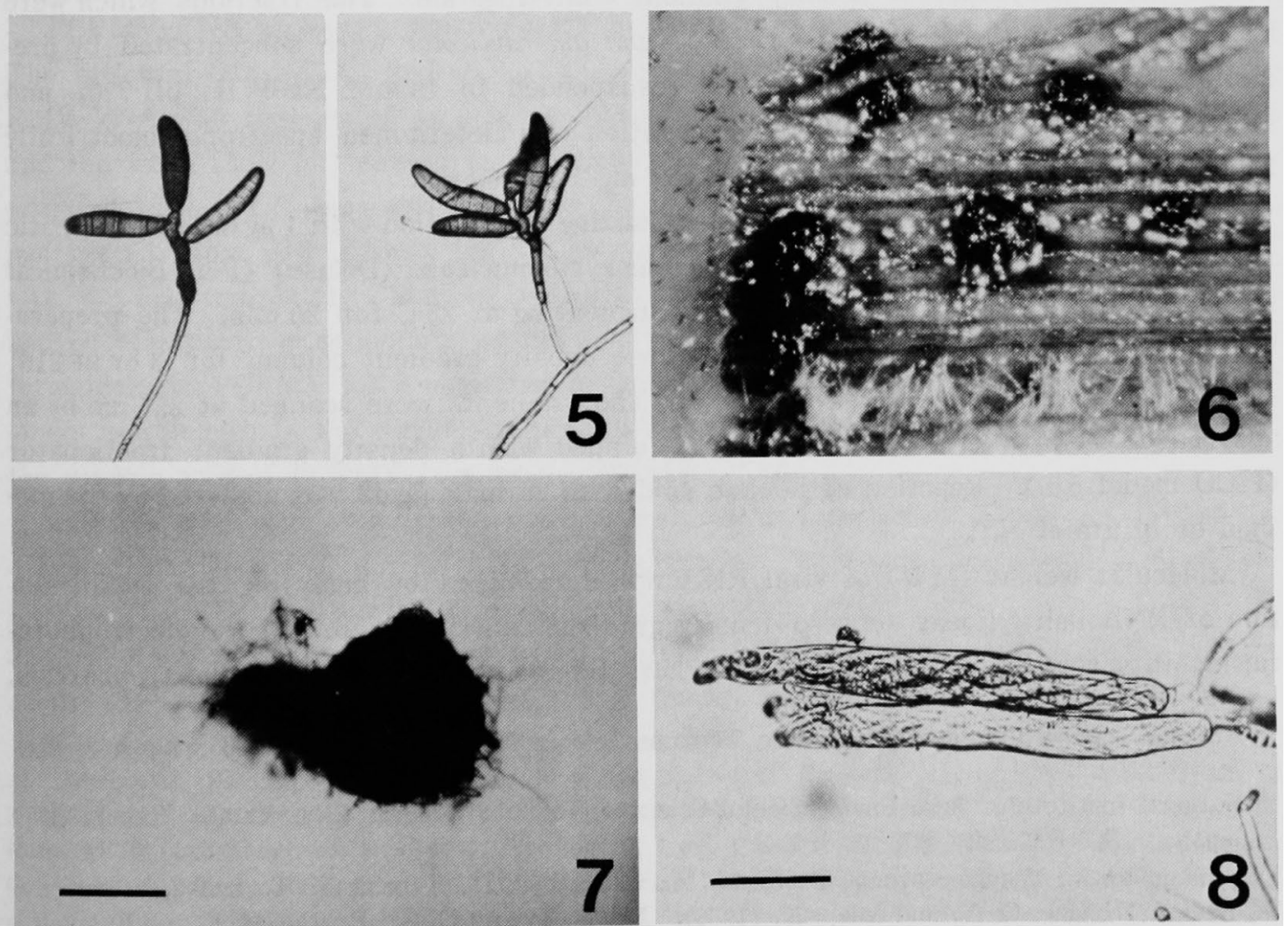